\title{
Formation of professional and communicative skills in the study of foreign languages in maritime specialties
}

\author{
Olga Kruchina, ${ }^{1, *}$, Alla Mikhaylova ${ }^{2}$ \\ ${ }^{1}$ Foreign languages department Kerch State Maritime Technological University Kerch, \\ Ordzhonikidze st. 82, Russian Federation \\ ${ }^{2}$ Foreign languages department Sevastopol State University Sevastopol, University st.33, Sevastopol, \\ Russian Federation
}

\begin{abstract}
The paper focuses on the perspectives of new pedagogical technologies of future specialists' professional and communicative skills formation in order to improve the quality of occupational training. Developed technologies of professional and communicative skills formation, including acmeological approach during the process of foreign language learning, are presented. It is necessary to take into consideration the category of maturity as an integral characteristic of the education results. That's why acmeological approach for effective development of students' professional communicative skills was proposed in this research. Analysis of the formative experiment results and systematic observation of educational activities of students proved the effectiveness of using acmeological approach. The authors made the conclusion that consistent and purposeful implementation of the proposed approach to the problem solution in the educational process of the university ensures the formation of professional and communicative skills of future specialists of maritime specialties.
\end{abstract}

\section{Introduction}

In terms of improving the quality of education, modernization of higher education modern maritime specialties should be competent in their professional activities and be able to develop their strategy and tactics, for implementing various ideas [11].

Modern maritime organizations need specialists who are able to use creatively in their professional activities the acquired knowledge at the university; who master the methods and techniques of their creative implementation in practical work; who feel the need to update and improve professionally significant knowledge and skills, which differ in the formation of professional principles, views, beliefs, interests, desires and motives of activity [1].

Such a task requires the higher school to organize the search for pedagogical measures to improve the effectiveness of the professional orientation of the student's personality, to

\footnotetext{
${ }^{*}$ Corresponding author: scorpion19.11@yandex.ru
} 
determine the ways of its permanent formation throughout the period of study at the university.

Analysis of the Federal State Educational Standard of Higher Education in the specialty 26.05.05 Navigation (specialty level) showed that among the necessary skills are the following:

- ability to communicate orally and in writing in Russian and foreign languages to solve problems of interpersonal and intercultural interaction (GC-6) [13];

- readiness for communication in Russian and foreign languages in oral and written forms to solve the problems of professional activity (GCP-2) [3];

- knowledge of English to the extent necessary to carry out specialists' functional responsibilities (PC-18).

The graduate of training direction 26.03.02 - Shipbuilding, Ocean Engineering and System Engineering of Sea Infrastructure Objects (bachelor's program) has to possess the corresponding general cultural competences: ability to communicate in Russian and foreign languages orally and in writing to solve problems of interpersonal and intercultural interaction (GCC-5) [14].

A graduate who has mastered the program of specialization in the specialty 26.05.01 Design and Construction of Ships and Objects of Ocean Engineering must have the appropriate general cultural competence: ability to communicate in Russian and foreign languages orally and in writing to solve problems of interpersonal and intercultural interaction (Federal State Educational Standard of Higher Education) [15].

To prepare for the changes in future, specialists will have to adapt to the new requirements for their skills. To have professional qualifications and communication skills - hard skills and soft skills - in the "new complex world" will not be enough. "Hard" and "soft" ones will include meta-skills. Media literacy, emotional intelligence and the ability to hold attention are part of the qualities that will be valued in the labor market in the future 2019-2022. These and other changes are discussed in the framework of the project session of the inter-university championship of World Skills Russia. The core of personality is the existential skills or metaskills. They are connected with the deep foundations of our actions and attitude to business [9]. This is awareness, vitality, creativity, determination, compassion and the desire for constant development.

\section{Problem statement}

Having analyzed the current state of higher education, we concluded that in the conditions of modern scientific and technological revolution there is a gap between the historical tradition of learning in higher education and the needs of society. In the content of the modernization of the professional education system, a transition to the use of modern methods and technologies of training aimed at continuous development and improvement of creative thinking, skills and motivation, identification and formulation of problems [11].

In accordance with the specifications of WorldSkills standards (WSSS) specialists should know and understand:

- principles of productive teamwork;

- principles of organization and behavior of systems; approaches that contribute to the effectiveness of products, strategies and practices;

- technologies for collecting information from various sources, analysing and evaluating information.

The following requirements are put forward to the communicative abilities and skills of interpersonal communication: a specialist must know and understand:

- the importance of listening; 
- the need to comply with the principles of discretion and confidentiality when working with partner;

- importance of resolving misunderstandings and conflicting requirements;

- the importance of creating and maintaining a trusting and productive working relationship with the partner;

- the value of the skills of clear and competent writing and speaking.

Professional and communicative skills taking into account Federal State Educational Standard of Higher Education requirements and WorldSkills standards are presented in table 1.1 .

The importance of these abilities is confirmed by the requirements of professional organizations of a number of European countries under the guidance of FEANI to professional and personal competencies of graduates (FEANI).

Thus, the relevance of this study is determined by the existing social and educational need for specialists with communication skills, ready for the professional activity, and the search for pedagogical conditions for the effective formation of communicative skills of students in the educational process of the university.

Table. Professional and communicative skills listed in Federal State Educational Standard of Higher Education requirements

\begin{tabular}{|l|l|}
\hline Specialties & Skills \\
\hline $\begin{array}{l}26.05 .05- \\
\text { Navigation }\end{array}$ & $\begin{array}{l}\text { ability to communicate orally and in writing in Russian and foreign languages } \\
\text { to solve problems of interpersonal and intercultural interaction, readiness for } \\
\text { communication in Russian and foreign languages in oral and written forms to } \\
\text { solve the problems of professional activity, knowledge of English to the extent } \\
\text { necessary to carry out their functional responsibilities }\end{array}$ \\
\hline $\begin{array}{l}\text { 26.03.02- } \\
\text { Enipbuilding, Ocean } \\
\begin{array}{l}\text { System Engineering } \\
\text { of Sea Infrastructure } \\
\text { Objects }\end{array}\end{array}$ & $\begin{array}{l}\text { ability to communicate in Russian and foreign languages orally and in writing } \\
\text { to solve problems of interpersonal and intercultural interaction }\end{array}$ \\
\hline $\begin{array}{l}\text { 26.05.01 - Design } \\
\text { and Construction of } \\
\text { Ships and Objects of } \\
\text { Ocean Engineering }\end{array}$ & $\begin{array}{l}\text { ability to communicate in Russian and foreign languages orally and in writing } \\
\text { to solve problems of interpersonal and intercultural interaction }\end{array}$ \\
\hline
\end{tabular}

Accelerating economic and social progress is crucial on the material and spiritual aspects of the life of the state as a whole and each individual personality, which required the development of innovative approaches to the educational process.

The quality of modern education has become an important subject of discussion of the pedagogical community. According to A.I. Subetto [6], the management of the future is possible in terms of development of human qualities, social intelligence and educational systems in society [6].

The higher school is designed to provide such conditions in which the possible transformation of personal and social goals into an effective internal incentive for professional and creative development of the future specialist, the development of an active professional position and creative style of activity. In our opinion, such conditions can be provided by acmeology. Acmeology (from the Greek. akme-the highest degree, the top) is a comprehensive science of man, located in the period of his/her maturity, i.e. the most productive period of life [8]. 
Acmeology has acquired a significance as a science that studies the rules of professionalism and skills development as "acme-forms" of optimal implementation of all kinds of professional activities.

Various aspects of professional learning were researched by psychologists and teachers such as A.K. Markova, N.D. Levitov, I.A. Zimnaya, V.V. Kraevsky, M.M. Levin, V.A. Slastenin, O.N. Shilov, A. S. Povidaichyk, and others.

One of the solutions for these problems is a training process formation with the support of acmeology theory (K.A. Abulkhanova-Slavskaya, A.A. Bodalev, N.V. Kuzmina, B.G. Ananev, A.A. Derkach and others).

In the pedagogical theory the techniques in the development of students' professional and communicative skills have not been researched yet. The question of the use of acmeology to solve the problem of the quality of education is not sufficiently studied. Acmeological concept of education is based on the following leading ideas: the purpose and result of the educational process is a development of a growing person, which is expressed in the integral quality of maturity at each milestone stage of learning and maturation.

\section{Research questions}

In the process of globalization, the students' professional mobility requires professional and communicative skills. Due to it, the future specialists have the opportunity to develop professional and communicative skills that one of the aims of education that is an education of harmonically and developed personality [9, p. 112].

The content of the pedagogical process should include innovative aspects of educational technologies. One of these aspects is stated to be an acmeological approach that stimulates the development of personal qualities needed for competitive specialist. It is acmeology that solves a very difficult task: to find out features of a person on each phase of his/her life that he/she must reach "acme".

We agree that it is necessary to refer to the category of maturity as an integral characteristic of the results of education, development and education of a person. Based on the understanding of personality as one of the essential characteristics of a person, his/her social development, it is necessary to recognize that personal maturity (mature personality) does not reveal all aspects of integral human development. Every age stage of development is associated with periods of training. It ends with reaching its peak, a state of a certain kind of maturity, the essence of which is readiness for development-education at a subsequent stage.

After analyzing the current state of higher education, we came to the conclusion that the level of formation of communicative skills that is the ability to relate language means with specific goals, situations and tasks of speech communication, students are low.

\section{Purpose of the study}

After The purpose of this article is an identification, theoretical justification and experimental verification of pedagogical technologies that contribute to the efficiency of future specialist's professional and communicative skills formation during the process of foreign language learning.

In accordance with the goal, the following tasks were set:

1) to determine the role of a foreign language in the future professional activity of a specialist as a means of communication;

2) to consider innovative technologies in order to improve the level of formation of communicative competence of students. 
With the purpose of formation of professional and communicative skills taking into account an acmeological approach it is necessary to carry out purposeful impact on the motivational and regulatory-activity sphere of the personality, his/her "micro-acme" at different age stages [1]. This integral criterion is a phenomenon of maturity, where maturity is a subjective-objective component that reflects personal life experience and natural resources of a growing person. In our case, maturity is a social result that arose in the process of interaction between the educational and social environment, it is a micro-acme, which was formed at the intersection of the following processes: age-related psychophysiological maturation and educational, where priority is given to the laws of socio-cultural development.

\section{Research methods}

Social maturity as an acme-form of a student includes the following indicators: the integrity of the worldview; sustainable professional choice and motivation for success; the ability to self-realization, self-development and self-improvement; the ability to adapt to society. Higher education orientation to the formation of social maturity can contribute to the integrity of the educational process and a higher level of quality. The implementation of acmeological theory in practice means the approach to solving the problems of continuity in learning, the stability of the development of professional creative abilities. The process of personality formation is associated with the self-determination of a person in the society in which his/her development takes place, in activity and communication with other people.

To solve the problem of verification of initial assumptions in the study, a set of complementary research methods is used:

- theoretical: (analysis of philosophical, sociological, psychological, pedagogical, social, engineering literature on the problem under consideration; analysis of documentation on the organization of the educational process at the university for the theoretical substantiation of the essence, functions, structural components of the model of formation of the future engineer of professional and creative skills; analysis, synthesis, and systematization for the theoretical generalization of the main approaches to solving the problem of research);

-empirical (study of documents, questionnaires, observation, interviews, testing, selfassessment, study of products, pedagogical design);

- experimental one.

For a more detail study of the socio-pedagogical conditions of the university, we have studied the following main points of training:

- transition features from the school program at the initial stage of training;

- improvement of the mechanism of self-control in the process of vocational training.

The program of discipline "Foreign language" is analyzed. The purpose of mastering the discipline "Foreign language" is to teach students active foreign language proficiency in the field of professional activity and the formation of their ability and readiness for intercultural communication, that is due to the communicative orientation of the discipline and competence-based approach to the organization of training.

\section{Findings}

The achievement of the goal is ensured by the formation of professional and communicative skills during the process of foreign language learning. The main goal is to increase the initial level of foreign language skills achieved at the previous level of education, and the acquisition of students with the necessary and sufficient level of communicative competence to solve social and communicative problems in various fields of cultural, 
professional and scientific activity in communication with foreign partners, as well as for further self-education.

At the stage of professional adaptation, an individual style of the future specialist's activity is also formed, which is based on his/her individual psychological characteristics [4]. The effective development of personality and the formation of professional consciousness contribute to the fact that the inclusion of students in the system of industrial and social relations takes place without disappointments, crises and conflicts. Comprehensive development of the individual is carried out throughout the life of the person and consists of mental, physical, moral, labor and aesthetic education and development.

The modern approach to teaching a foreign language is to build it on a technological basis, directly related to pedagogical and methodological principles, namely: the principle of communicative orientation of "Foreign language" course, the principle of cultural and pedagogical expediency, the principle of integration of knowledge from various subject disciplines, the principle of nonlinearity and the principle of autonomy of the student [10].

The "Foreign language" course is based on the following acmeological technologies:

- technology of interactive learning, providing formation and development communication skills (work in pairs, brainstorming, training, work in small groups in the classroom and independently via the Internet);

- personality-oriented technologies (differentiated tasks, multi-level tests with varying degrees of text complexity, development of individual routes);

- modular-block technologies (organization of educational and cognitive activity individual training program, based on the concept of a modular approach to learning);

- information and communication technologies (use of authentic video and audio programmes, videoconferencing, etc.));

- integrated technologies (problem method, modeling of situations, various tasks focused on the profession, work in pairs and mini-groups);

- project technologies (individual, group, presentations, presentations at conferences in a foreign language);

- method of analysis of real situations (case-stage) (case-text with questions for discussion; applications with a selection of different information, transmitting the general context of the case);

- language portfolio, or portfolio, serves to assess the level of competence in the field of foreign languages and can serve as a starting assessment of the level of achievement, midterm and intermediate control. The main task of creating a portfolio-involvement is in the understanding of learning outcomes and setting goals for future development in a specific subject area (evaluation forms, online shells for web sites).

Innovative pedagogical technologies provide independence of experimental and research orientation of training. The use of innovative technologies in the process of practical training course "Foreign language" implements the basic principle of the communicative workshopthe creation of favorable conditions for the free creative implementation of the skills of speech professional communication and the search for creative non-standard approach to solving the problem. Role-playing games and communicative professional trainings are actively involved in the educational process. Synthesis of two techniques ("training" and "game") allows to solve a number of important tasks on communicative adaptation of future specialists, such as: phonemic speech; automation of speech normalization; methodological and practical orientation in the field of research, the development of stylistic "flair"; the creation of creative personality (creative) motivation; expanding the ideological base.

Communication-training games are innovative teaching technologies, aimed at modeling specific communicative situations and allowing students not only to practice their theoretical knowledge, but also learn to adapt to the designated context (not always positive), and to analyze speech and nonverbal behavior of game participants. 
Authentic text materials in a foreign language must be accompanied by visual illustrations and various types of communicative exercises. The system of exercises includes exercises aimed at: developing skills different types of reading; mastering of special vocabulary in the professional direction; formation of skills of professional oral speech (dialogue and monologue).

Modern universal way of education, which combines the technology of traditional and elearning and meets the individual requirements of students is the blended learning [12]. The most important difference between the blended learning and the traditional learning model is the use of a combination of forms of education in real and virtual educational space, combinations traditional teaching methods with e-learning technologies.

A high level of achievement motivation means that the student is dominated by the pursuit of success; a low level of motivation, on the contrary, indicates that the desire to avoid failure dominates [5].

For diagnosis we used the technique of personality diagnostics on motivation to success by T. Ehlers (Test/Questionnaire T. Ehlers for the study of motivation to succeed) and a technique of diagnostics of personality on motivation to avoid failures of the T. Ehlers. The results of the ascertaining experiment showed a generally insufficient level of achievement motivation, which confirmed the need for trainings development. The purpose of the formative experiment was to include students in the process of mastering the specialty on the basis of the ideas of acmeological, communicative, contextual, personality-oriented and personality-activity approaches using active forms and methods of learning.

Engineering approaches for the formation of competencies are quite complex $[15,16]$.

Comparative analysis of the results of ascertaining (stage I) and forming (stage II) experiments showed that the level of professional and communicative skills formation in students of the experimental group compared with ascertaining experiment tends to increase. The level of formation in the control group has not changed. The results were summarized in the diagrams 1-2.

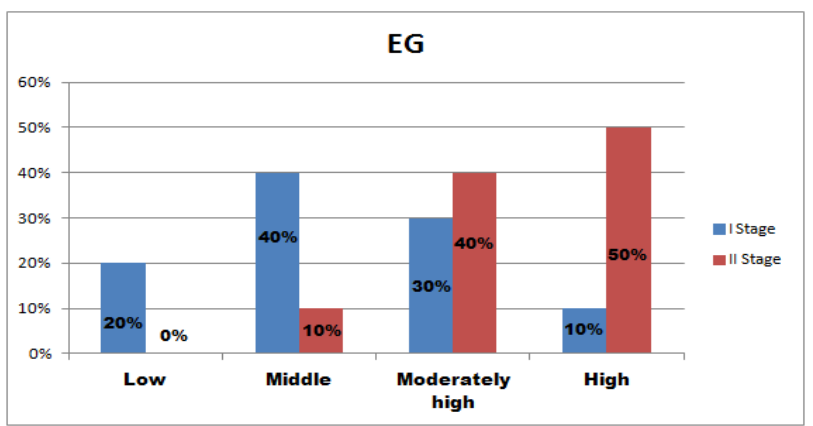

Fig. 1. Changes in the number of students EG (experimental group), belonging to different levels of professional and communicative skills formation (\%).

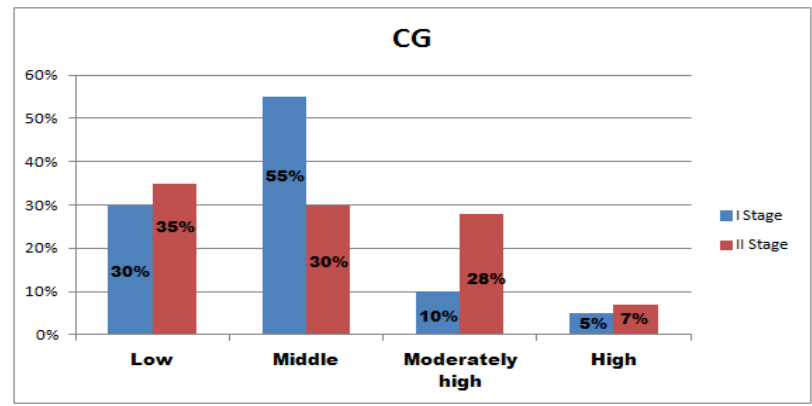


Fig. 2. Changes in the number of CG (control group) students, belonging to different levels of professional and communicative skills formation (\%).

Analysis of the results of the formative experiment and systematic observation of educational activities of students revealed the effectiveness of the acmeological approach, in particular, training: students of the experimental group have reached a higher level of achievement motivation compared to the students of the control group. We have recorded a positive dynamics of the motivational component development in the experimental group students in the process of professional education.

\section{Conclusion}

Thus, the analysis of the professional state of higher education has shown that the level of formation of communicative skills in higher students are insufficient, which requires the use of innovative technologies in the process of learning a foreign language. One needs technologies that allow to solve the contradiction between the society's need for competent specialists who are ready to use communication skills to solve professional problems, and the actual level of readiness of graduates to perform their basic professional functions.

The implementation of acmeological theory in practice is the approach to solving the problems of continuity in learning, the stability of the development of professional and communicative skills.

The results of our experiment show that consistent and purposeful implementation of the developed approach to the problem solution in the educational process of the university ensures the effectiveness of professional and communicative skills forming in future specialists of maritime profile, which significantly improves the quality of professional training.

\section{References}

1. I. V. Balynin., A. G. Mikhaylova, N. N. Nizhneva, "Promote Development of Knowledge Intensive Activities on the Basis of Improving Management Training by Means of Acmeological Approach", Advances in Social Science, Education and Humanities Research, volume 24, 2nd International Scientific Conference on New Industrialization: Global, National, Regional Dimension, SICNI, pp. 302-306 (2018)

2. http://www.feani.org/EUR_ACE/EUR_ACE_Main_Page.htm. (Last accessed 04.04.2019)

3. Chen, Minghui Multimodal, "Analysis in Academic Settings: From Research to Teaching”, Visual Communication, vol.17, Issue 4, pp. 475-478 (2018)

4. V. A. Norin, N. V. Norina, Y. V. Pukharenko, "Interactive Methods of teaching at Russian Engineering Universities", Education and Information Technologies, vol.23, Issue 6, pp. 2801-2820 (2018)

5. Oki Sutopo, Rahadianto, Nilan, Pam, "The Constrained Position of Young Musicians in the Yogyakarta Jazz Community”, Asian music. vol. 49, Issue 1, pp. $34-57$ (2018)

6. A. I. Subetto, "Noospheric Smysloviye", 262 p. (Saint-petersburg, Kostroma, KSU named after N.A. Nekrasov, "Asterio", 2014)

7. Leila Tajik, Ranjbar, Kobra, "Reflective Teaching in ELT: Obstacles and Coping Strategies", Journal of research in applied linguistics, vol. 9, Issue 1, pp. 148-169 (2018)

8. B. A. Turgunbayeva, E. Martišauskienè, B. Z. Bekzhanova, V. K. Kelsievna, "Acmeologic bases of scientific and pedagogical personnel training in the conditions of masters program”, Pedagogy 2014, vol. 113, 1, pp. 76-891 (2014) 
9. URL: $\quad$ https://worldskills.ru/media-czentr/novosti/ekaterina-loshkareva-model«tverdyix»-i-«myagkix»-navyikov-ustarela.html (Last accessed 02.05.2019)

10. G. V. Balashova, L. R. SHabajkina, "Inostrannyj yazyk v pravovedenii: rabochaya programma" Moskva-Orenburg: Moskovskij gosudarstvennyj yuridicheskij universitet im. O.E. Kutafina, 47 p. (MGYUA, 2016)

11. A. G. Mihajlova, "Koncepciya formirovaniya professional'no-tvorcheskih umenij u budushchih inzhenerov na osnove akmeologicheskogo podhoda", Istoricheskaya i social'no obrazovatel'naya mysl', Vol., 8, 6(1), pp. 206-211 (2016) doi: 10.17748/20759908-2016- 8-6/1--6/1-206- 211.

12. T. P. Popova, T. A. Nenasheva, "Informacionnye tekhnologii v obuchenii inostrannym yazykam v vuze (model' smeshannogo obucheniya)", Istoricheskaya i social'noobrazovatel'naya mysl', Tom. 8, 6(1), pp. 218-226 (2016) URL: http://fgosvo.ru/uploadfiles/ProjectsFGOSVO/SPEC/260505_C.pdf

13. URL: https://classinform.ru/fgos/26.03.02-korablestroenie-okeanotekhnika-isistemotekhnika-obektov-morskoi-infrastruktury.html (Last accessed 12.05.2019)

14. URL:

http://www.consultant.ru/document/cons_doc_LAW_187580/2c0e50fe237577bdd7f91 4be80bb9456c4db7746/ (Last accessed 17.05.2019)

15. S. Sokolov, A. Zhilenkov, S. Chernyi, A. Nyrkov, D. Mamunts, "Dynamics Models of Synchronized Piecewise Linear Discrete Chaotic Systems of High Order", Symmetry, vol. 11, 2, p. 236 (2019) Available: 10.3390/sym11020236.

16. N. Glebov, A. Zhilenkov, S. Chernyi, S. Sokolov, "Process of the Positioning Complex Modeling Objects with Elements of Intellectual Analysis", Procedia Computer Science, vol. 150, pp. 609-615 (2019) Available: 10.1016/j.procs.2019.02.094 